\title{
BEST PRACTICE PENGELOLAAN MADRASAH IBTIDAIYAH BERBASIS PESANTREN DI YOGYAKARTA
}

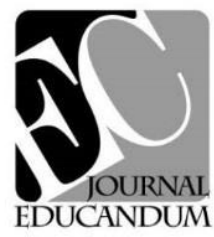

\section{Aji Sofanudin, Nugroho Eko Atmanto \& Rahmawati Prihastuty*}

\author{
Balai Penelitian dan Pengembangan Agama Semarang, JI Untung Suropati Kav 69-70 Ngaliyan Semarang \\ Email: ajisofan@gmail.com, HP 08174151699
}

Balai Penelitian dan Pengembangan Agama Semarang, JI Untung Suropati Kav 69-70 Ngaliyan Semarang Email:nugroho.blas@gmail.com, HP 085866275800

Jurusan Psikologi Fakultas IImu Pendidikan UNNES, Kampus FIP UNNES Gunung Pati Semarang Email:rahmawati.prihastuty@mail.unnes.ac.id, HP 08122822939

INFO ARTIKEL
Keywords: Madrassa, Management, Wahid Hasyim

\begin{abstract}
ABSTRAK
Penelitian ini bertujuan untuk mengetahui praktik terbaik pengelolaan madrasah di Yogyakarta. Penelitian ini dilakukan dengan menggunakan metode kualitatif studi kasus pada MI Wahid Hasyim Yogyakarta. Hasil penelitian menunjukkan bahwa pengelolaan pada MI Wahid Hasyim terintegrasi dengan Ponpes Wahid Hasyim. Madrasah ini mengikuti seluruh kebijkaan yang diterapkan dinas pendidikan, kebijakan kantor kementerian agama, serta aturan Pondok Pesantren Wahid Hasyim. Rintisan MI Wahid Hasyim berdiri sejak tahun 1966, dengan nama MI Ma'arif Gaten di bawah pengelolaan LP Ma'arif. Tahun 1995 berubah menjadi MI Wahid Hasyim dibawah pengelolaan pesantren. Sejak tahun 2018 ruang belajar MI Wahid Hasyim berpindah dari pesantren, Jl Wahid Hasyim No 3 ke Gedung MI yang baru di Jl Cendrawasih No 1 Condongcatur menempati tanah desa. Jumlah siswa MI sebanyak 224 anak; sebagian mengikuti pembelajaran full day dan sebagian (sekitar $40 \%$ ) adalah mondok. Jumlah SDM pendidik dan tenaga kependidikan secara formal berjumlah 24 guru, tetapi secara faktual jumlahnya lebih banyak karena dibantu oleh para mahasantri PP Wahid Hasyim. Berdasarkan data dokumen diperoleh informasi bahwa pembelajaran pada MI Wahid Hasyim menggunakan STEAM (science, technology, engginering, art and mathematics) pada lintas ilmu yang dapat membentuk pola pikir logis dan sistematis dalam rangka mencapai visi "moslem generation, future leader".
\end{abstract}

\section{ABSTRACT}

This research aims to know the best practice of management madrassa in Yogyakarta. This research was conducted using qualitative case study at MI Wahid Hasyim Yogyakarta. The results found that management at MI Wahid Hasyim was integrated with pesantren. This madrassa follows all policies implemented by the education office, ministry of religious affairs, and the rules of pesantren. MI Wahid Hasyim was founded since 1966, under the name MI Ma'arif Gaten under the management of LP Ma'arif. In 1995 it changed to MI Wahid Hasyim under the management of a pesantren. Since 2018 MI Wahid Hasyim MI Wahid Hasyim has moved from the pesantren, Jl Wahid Hasyim No 3 to the new MI building on Jl Cendrawasih No 1 Condongcatur occupying village land. The number of MI students is 224 childrens; some take full day learning and some (about 40\%) are boarding. The number of human resources for educator is formally 24 people, but in fact the number is more because they are assisted by santri of PP Wahid Hasyim. Based on document, it is known that learning at MI Wahid Hasyim used STEAM (science, technology, engineering, art and mathematics) across disciplines that can form a logical and systematic mindset in order to achieve the vision of "moslem generation, future leader" 


\section{PENDAHULUAN}

Guru Besar Ilmu Pendidikan Islam UIN Sunan Kalijaga, Sutrisno, menyebutkan bahwa maksud awal didirikannya madrasah yaitu untuk mengumpulkan keunggulan pada pesantren dan keunggulan pada sekolah dalam satu satuan pendidikan. Keunggulan yang dimiliki oleh pesantren adalah penguasaan pada ilmu-ilmu keislaman, sedangkan keunggulan sekolah umum adalah penguasaan pada ilmu-ilmu umum. Pendirian madrasah dimaksudkan untuk mengumpulkan keunggulan ilmu keislaaman sebagaimana pesantren dan kompetitif dalam pemahaman ilmu-ilmu umum. Fakta bahwa kualitas madrasah kalah dibandingkan dengan pesantren dalam ilmu keislaman dan kalah bersaing dengan sekolah umum dalam ilmu-ilmu umum menjadi sesuatu yang tidak sesuai dengan harapan pendiriannya, sehingga penyelenggaraan pendidikan di madrasah harus diselaraskan kembali dengan tujuan awal pendirian lemabaga tersebut (Sofanudin, 2016a).

Mafhum bahwa karakteristik madrasah beragam. Ada madrasah mandiri, madrasah kompleks (MI, MTs, dan MA), serta ada madrasah yang berbasis pesantren. Semua tipe madrasah mengemban tugas yang sama yakni memberikan teladan terbaik dalam pengelolaan pendidikan. Undang-undang Nomor 20 Tahun 2003 tentang Sistem Pendidikan Nasional, Pasal 40 ayat $2 \mathrm{c}$ menyebutkan bahwa pendidik dan tenaga kependidikan berkewajiban: memberikan teladan dan menjaga nama baik lembaga, profesi, dan kedudukan sesuai dengan kepercayaan yang diberikan kepadanya.

Salah satu best practice madrasah dilakukan dengan mengembangkan prinsip humanis dan religius sesuai dengan nilainilai dasar humanis yang masih dalam ruang lingkup religius. Humanisme yang dikembangkan tidak bersifat sekuler, melainkan hasil penyesuaian dengan nilainilai religius (ilmu, aqidah, ibadah, akhlak, ma'rifah) (Hibana, Kuntoro, \& Sutrisno, 2015). Pengelolaan madrasah perlu menjadi contoh bagi lembaga pendidikan lainnya. Guru dan tenaga kependidikan madrasah perlu menjadi uswatun hasanah dan menjaga nama baik lembaga dan profesinya.

Nilai-nilai religius menjadi ciri utama lembaga pendidikan madrasah. Madrasah telah memberikan banyak praktik terbaik, baik dalam pembelajaran maupun pengelolaannya. Beberapa madrasah telah melakukan inovasi Pendidikan (Aji Sofanudin, Rokhman, Wasino, \& Rusdarti, 2016). Salah satu madrasah yang telah melakukan inovasi adalah MI Wahid Hasyim Yogyakarta (Sofanudin, 2016a). Penelitian ini bertujuan untuk mengetahui praktik pengelolaan MI Wahid Hasyim Yogyakarta. Pengelolaan pendidikan merupakan cara baru mengelola madrasah, memiliki hasil luar biasa, berkelanjutan, dan mampu menginspirasi pihak lain untuk mengadopsi.

Salah satu indikator madrasah bermutu adalah madrasah yang diminati oleh masyarakat (Sofanudin, 2012a). MI Wahid Hasyim Yogyakarta merupakan contoh madrasah berbasis pesantren yang banyak diminati masyarakat. Salah satu unsurnya adalah karena siswa MI Wahid Hasyim berasal dari berbagai macam daerah. MI Wahid Hasyim terbawa nama besar pondok pesantren Wahid Hasyim sehingga menarik minat masyarakat. MI Wahid Hasyim yakni inovasi di berbagai bidang: kurikulum, sumber daya manusia, dan pembelajaran. Best practice MI Wahid Hasyim adalah integrasi antara pembelajaran madrasah dengan pesantren. Hasil integrase ini dapat terlihat pada implementasi kurikulum di madrasah yang memadukan kurikulum satu (kurikulum formal) dan kurikulum dua (kurikulum pesantren/diniyah) untuk menghasilkan kurikulum yang lebih komprehensif. Madrasah berbasis pesantren merupakan salah satu keunggulan madrasah. Kelas dibagi menjadi tiga model: kelas biasa, kelas tahfidz, dan kelas asrama. Seiring perkembangan waktu, pengelolaan madrasah bisa saja mengalami kemunduran. 


\section{KAJIAN TEORI}

Ada adagium menyatakan bahwa tidak ada madrasah yang jelek, yang ada adalah pengelolaan madrasah yang tidak baik. Faktor pengelolaan menjadi kata kunci peningkatan mutu madrasah. Pengelolaan madrasah dalam kerangka peningkatan mutu terdiri atas lima aspek, yakni: manajemen, pemanfaatan teknologi dalam pembelajaran, budaya kerja tim, optimalisasi perangkat pembelajaran yang tersedia dan keterlibatan guru, siswa, orang tua, serta stakeholder terkait (Arif, 2013).

Mutu Pendidikan menurut Sallis terdiri atas mutu standar dan mutu persepsi (Sallis, 2014). Dalam konteks sekolah/madrasah mutu standar adalah mutu akreditasi lembaga. Madrasah ibtidaiyah yang bermutu adalah madrasah yang memiliki nilai akreditasi yang tinggi berdasarkan penilaian assessor BAN S/M. Mutu persepsi merupakan mutu berdasarkan penilaian konsumen. Dalam konteks madrasah, animo masyarakat yang tinggi terhadap suatu lembaga merupakan bukti bahwa lembaga tersebut tersebut. Olah karena itu, mutu madrasah setidaknya mengandung dua hal: akreditasi yang bagus sekaligus diminati oleh masyarakat. Untuk mendapatkan dua hal tersebut, madrasah idealnya sudah membuktikan dengan best practice yang dilaksanakan.

Best practice bermakna praktik terbaik dari keberhasilan individu atau kelompok dalam menyelesaikan tugas, termasuk persoalan dalam lingkungan tertentu (Kemendikbud, 2016). Best practice menjadi pengalamatan terbaik yang dari kepala madrasah dalam pelaksanaan tugas dan fungsi sebagai pemimpin madrasah. Oleh karenanya, terdapat lima kompetensi yang wajib dimiliko oleh kepala sekolah, diantanya: (1) kompetensi kepribadian; (2) kompetensi manajerial; (3) kompetensi kewirausahaan; (4) kompetensi supervise; dan (5) kompetensi sosial. Wujud best practice kepala dan guru madrasah tercermin dalam akreditasi dan persepsi masyarakat yang tinggi terhadap madrasah.
Beberapa indikator kepala/guru dengan best practice yaitu (1) berinovasi dalam mengatasi masalah Pendidikan, khususnya dalam pembelajaran; (2) mampu membawa perubahan atau perbedaan dengan hasil yang optimal; (3) mampu mengatasi masalah tertentu secara berkelanjutan (mempertahankan pencapaian), bermanfaat dan berdampak secara berkelanjutan (tidak sesaat); (4) mampu menjadi model yang menginspirasi dalam menyusun kebijakan (pejabat) dan perorangan, termasuk murid; (5) cara dan metode yang efektif dan efisien dalam penyusunan kebijkan, terutama terkait pembelajaran

(http://jatengonline.com/2017/05/19/ nugroho-s-pd-m-pd-juara-i-nasionalpenulisan-best-practice-kepala-sekolah/). Praktik terbaik pengelolaan pendidikan tercermin dalam pengelolaan kurikulum (Sofanudin, 2019), bisa menerapkan prinsip budaya damai dan menghadapi ikhtilaf dengan cara bijak (Maknun, 2014), integrasi Pendidikan antara pendidikan formal dan non formal (Sofanudin, 2018). Praktik terbaik pengelolaan Pendidikan bisa terjadi pada pesantren, madrasah maupun sekolah. Selain itu bisa juga terjadi pada madin (Taruna, 2009) maupun sekolah alam (Sofanudin, 2019).

Pengelola madrasah telah melakukan berbagai upaya untuk meningkatkan daya tarik madrasah di antaranya dengan memiliki program unggulan, membiasakan akhlak mulia, alumni banyak diterima di lembaga favourit, memiliki prestasi akademik dan non akademik yang baik (Sofanudin, 2012b)(Sofanudin, 2016b). Berdasarkan hasil FGD dengan kabid Dikmad Kemenag DIY, kasi kemenag kab sleman, dan penilaian peneliti disimpulkan bahwa madrasah unggul berbasis pesantren di Yogyakarta meliputi: MI Sunan Pandanaran, MI Wahid Hasyim dan Afkaaruna Islamic School (Sofanudin, 2020). 


\section{METODE}

Penelitian ini merupakan penelitian kasus (case study) pada madrasah Ibtidaiyah unggul di Yogyakarta. Pengumpulan data dilakukan dengan menggunakan observasi, wawancara, dan telaah dokumen. Peneliti berkunjung ke kanwil kementerian agama Provinsi Yogyakarta dan serta melakukan wawancara dengan Kabid Dikmad, Staf Dikmad, dan Kabag TU. Selain itu, peneliti juga berkunjung ke Kasi Dikmad Kabupaten/Kota di Wilayah Propinsi DIY yaitu di Kota Yogyakarta dan Kabupaten Sleman. Pengumpulan data juga salah satunya dilakukan di MI Wahid Hasyim. Sumber data primer adalah kepala dan para guru madrasah. Sumber sekunder adalah dokumen-dokumen madrasah, profil, serta dokumen kurikulum. Analisis data dilakukan dengan evaluatif-deskriptif. Waktu pengumpulan data dilakukan mulai 23 Agustus 2020 s.d 1 September 2020 di mana penanganan Covid-19 masih belum selesai.

\section{TEMUAN DAN PEMBAHASAN}

Meskipun bukan daerah basis madrasah, namun jumlah madrasah di Propinsi DIY cukup banyak, terutama madrasah ibtidaiyah. Berikut ini adalah jumlah madrasah ibtiadiyah yang ada di DIY berjumlah 186 lembaga.

Tabel 1 Jumlah Madrasah Ibtidaiyah di Yogyakarta

\begin{tabular}{lllll}
\hline $\begin{array}{l}\mathrm{N} \\
\mathrm{o}\end{array}$ & $\begin{array}{l}\text { Kabupaten/K } \\
\text { ota }\end{array}$ & $\begin{array}{l}\text { Madrasah } \\
\text { Ibtidaiyah }\end{array}$ \\
\cline { 3 - 5 } & \multicolumn{3}{l}{ Negeri } & Swasta Jumlah \\
\hline 1 & Bantul & 3 & 30 & 33 \\
\hline 2 & Gunung Kidul & 12 & 69 & 81 \\
\hline 3 & $\begin{array}{l}\text { Kota } \\
\text { Yogyakarta }\end{array}$ & 1 & 3 & 4 \\
\hline 4 & Kulon Progo & 3 & 28 & 31 \\
\hline 5 & Sleman & 2 & 35 & 37 \\
\hline Jumlah & 21 & 165 & 186 \\
\hline
\end{tabular}

Sumber: Data Kanwil Kemenag Provinsi Yogyakarta 2020/2021

Mayoritas MI ada di kabupaten gunung kidul yakni sebanyak 81 lembaga. Menurut kabid dikmad propinsi DIY, meksipun banyak madrasah namun secara umum kualitas MI di Gunung Kidul sama, tidak ada yang menonjol. Justru yang menonjol ada di Kabupaten Kota dan Sleman (Wawancara, 24/8/2020).

Di kabupaten Sleman jumlah madrasah lebih banyak daripada di Kota Yogyakarta. Berikut ini persebaran MI di Kabupaten Sleman di 17 Kecamatan

Tabel 2 MI di Kabupaten Sleman

\begin{tabular}{llll}
\hline No & Kecamatan & \multicolumn{2}{l}{$\begin{array}{l}\text { Madrasah } \\
\text { Ibtidaiyah }\end{array}$} \\
\cline { 3 - 4 } & & Negeri & Swasta \\
\hline 1 & Berbah & 0 & 0 \\
\hline 2 & Cangkringan & 0 & 1 \\
\hline 3 & Depok & 0 & 4 \\
\hline 4 & Gamping & 0 & 3 \\
\hline 5 & Godean & 0 & 1 \\
\hline 6 & Kalasan & 0 & 2 \\
\hline 7 & Minggir & 0 & 0 \\
\hline 8 & Mlati & 1 & 2 \\
\hline 9 & Moyudan & 0 & 1 \\
\hline 10 & Ngaglik & 1 & 4 \\
\hline 11 & Ngemplak & 0 & 1 \\
\hline 12 & Pakem & 0 & 1 \\
\hline 13 & Prambanan & 0 & 0 \\
\hline 14 & Sayegan & 0 & 3 \\
\hline 15 & Sleman & 0 & 6 \\
\hline 16 & Tempel & 0 & 4 \\
\hline 17 & Turi & 0 & 1 \\
\hline Jumlah & 2 & 34 \\
\hline
\end{tabular}

Sumber: Data Emis, 2020

Data kuantitas madrasah secara mudah bisa didapatkan. Namun, data kualitas/mutu madrasah itu beragam. Ukuran mutu yang digunakan bisa berbedabeda. Sebagaimana disampaikan oleh pejabat di Kementerian Agama Kabupaten Sleman (Wawancara Ahmad Fauzi, Kasi Dikmad Kankemenag Kab Sleman (24/8/2020)

Madrasah unggul di Sleman itu banyak, tinggal ukurannya apa. Kalau ukurannya animo masyarakat dalam arti jumlah siswa, maka itu MI Sunan Pandanaran. Tapi jika ukurannya adalah kesejarahan dan akreditasi maka MI Wahid Hasyim. 
MI Afkaruna juga bagus, berwawasan global. Ini bisa disebut sebagai madrasah internasional, bahasa keseharian menggunakan bahasa Inggris.

Meskipun demikian, secara umum mutu madrasah ditentukan oleh mutu standar yaitu mutu akreditasi. Mutu standar yang diakui secara umum adalah perolehan nilai akreditasi yang dikeluarkan oleh BAN S/M.

Tabel 3 Mutu Madrasah Ibtidaiyah Mutu madrasah berdasarkan akreditasi tertinggi:

$\begin{array}{lll}\text { No } & \text { Lembaga } & \text { Akreditasi } \\ 1 & \text { MIS Ma'arif Bego } & 98 \\ 2 & \text { MIN Jejeran } & 97 \\ 3 & \text { MIN Kebonagung } & 97 \\ 4 & \text { MIN Yogyakarta II } & 97 \\ 5 & \text { MIN Semanu } & 95 \\ 6 & \text { MIN Rongkop } & 95 \\ 7 & \text { MIS Wahid Hasyim } & 95 \\ 8 & \text { MIN Wonosari } & 94 \\ 9 & \text { MIN Tepus } & 94 \\ 10 & \text { MI Al Khoiriyah } & 94 \\ & \text { Wonolelo } & \\ 11 & \text { MIS Sultan Agung } & 94\end{array}$

Sumber: Kanwil Kemenag Yogyakarta, 2020 diolah

Salah satu madrasah yang dianggap bermutu (memiliki nilai akreditasi tinggi) dari madrasah berbasis pesantren adalah MI Wahid Hasyim. Madrasah ini berada di bawah pengelolaan Yayasan Pondok Pesantren Modern Wahid Hasyim. MI Wahid Hasyim terletak di jalan Cendrawasih No 01, Pringwulung, Condongcatur, Depok, Sleman Yogyakarta. Keberadaan MI Wahid Hasyim bisa dilihat pada website resmi: mi.ppwahidhasyim, IG miwahidhasyim, fb: MI Wahid Hasyim Yogyakarta, email: mi.weha@yahoo.com, telp 0274-5021902. Secara geografis, posisi Madrasah Ibtidaiyah Wahid Hasyim Yogyakarta berada pada lokasi strategis dan berdekatan dengan pusat kota. Pesantren Wahid Hasyim berada pada lokasi strategis. Lokasinya terletak dekat kota yaitu, jalan utama Yogyakarta-Solo, dekat dengan kampus ternama seperti UNY, UIN Sunan Kalijaga, Universitas Gadjah
Mada, Amikom, Akakom, Universitas Islam Indonesia, Kampus UPN dan pusat- pusat kebudayaan (Perpustakaan Bung Hatta, Museum Udara Adi Sucipto, Museum Benteng Vanderberg, Candi Prambanaan, Meseum Affandi, Monjali, serta Keraton Ngayogyakarta Hadiningrat).

Pada mulanya MI Wahid Hasyim berada satu kompleks dengan lokasi pesantren, yakni berada di Jl Wahid Hasyim Nomor 3 Gaten Condong Catur, Depok Sleman. Mulai tahun 2108, lokasi MI Wahid Hasyim pindah lokasi di Jl Cendrawasih Nomor 1 Pringwulung Condongcatur.

Tabel 4 Sejarah MI Wahid Hasyim

\begin{tabular}{|c|c|c|c|}
\hline No & $\begin{array}{l}\text { Nama } \\
\text { Lembaga }\end{array}$ & Periode & Keterangan \\
\hline \multirow[t]{2}{*}{1} & MI & $1966-$ & Di bawah LP \\
\hline & $\begin{array}{l}\text { Ma'arif } \\
\text { Gaten }\end{array}$ & 1994 & Ma'arif \\
\hline \multirow[t]{7}{*}{2} & MI & $1995-$ & Di bawah PP \\
\hline & Wahid & Sekarang & Wahid \\
\hline & Hasyim & & Hasyim; \\
\hline & & & $\begin{array}{l}\text { lokasi } \\
\text { menyatu }\end{array}$ \\
\hline & & & dengan PP \\
\hline & & & Wahid \\
\hline & & & Hasyim \\
\hline \multirow[t]{10}{*}{3} & & $2018-$ & Lokasi \\
\hline & Wahid & Sekarang & pembelajaran \\
\hline & Hasyim & & pindah ke Jl \\
\hline & & & Cendrawasih \\
\hline & & & No 01 \\
\hline & & & Pringwulung \\
\hline & & & Condong \\
\hline & & & Catur. \\
\hline & & & Kepala \\
\hline & & & Madrasah \\
\hline
\end{tabular}

Lokasi MI Wahid Hasyim strategis karena berada di tengah masyarakat perkotaan. Batas MI Wahid Hasyim menurut letak geografis sebagai berikut:

1. Bagian utara berbatasan Wisata Kuliner Pringwulung

2. Bagian timur berbatasan Dusun Gaten

3. Bagian barat berbatasan Dusun Pringwulung

4. Bagian selatan berbatasan Dusun Nologaten 
MI Wahid Hasyim menjadi lembaga pendidikan formal yang dikelola oleh Yayasan Pondok Pesantren Wahid Hasyim. Dilihat dari sejarah, madrasah ini semula bernama MI Ma'arif Gaten berdiri pada tanggal 11 April 1966, berada dalam pengelolaan Lembaga Ma'arif NU. Seiring perjalanan waktu, 1 November 1995 MI Ma'arif Gaten berubah menjadi MI Wahid Hasyim dengan status perijinan (terdaftar) dari Departemen Agama yang diperoleh sejak tertanggal 6 Januari 1995. Status MI Wahid Hasyim menjadi "diakui" pada 9 Maret 2000. Pada 28 Oktober 2011, melalui SK BAN Provinsi, Nomor: 28.2/BAP/TU/X/2011 tentang penetapan hasil akreditasi Sekolah/Madrasah MI Wahid Hasyim memperoleh akreditasi A. Pada tahun 2016 kembali MI Wahid Hasyim memperoleh akreditasi A dengan nilai cukup tinggi yaitu 95 .

MI Wahid Hasyim memiliki tugas menyiapkan dan mengembangkan SDM berkualitas. Visi MI Wahid Hasyim yaitu “Terwujudnya Generasi Qur'ani Unggul dalam Prestasi”. Adapun misinya adalah (1) menyelenggarakan pendidikan keagamaan Islam (kajian keilmuan maupun amaliyah keseharian); (2) menyelenggarakan pembinaan pengembangan pribadi berakhlakul karimah; (3) menyelenggarakan pembinaan Tahsin dan Tahfudzul Qur'an; (4) menyelenggarakan Pembinaan Bahasa Arab dan Inggris, dan (5) menyelenggarakan pembinaan pengembangan kreativitas dan keterampilan anak didik sesuai potensi dan bakat minat siswa.

Sejak tahun 2018, MI Wahid Hasyim pindah lokasi pembelajaran di Jl Cendrawasih No 1 Pringwulung Condongcatur. Keadaan Gedung MI Wahid Hasyim adalah adalah sebagai berikut

Tabel 5 Keadaan Gedung

\begin{tabular}{llcc}
\hline No & Keadaan & Baik & Rusak \\
\hline 1 & Rumang Kelas & 10 & 10 \\
\hline 2 & Ruang Guru & 1 & 1 \\
\hline
\end{tabular}

\begin{tabular}{llll}
\hline 3 & $\begin{array}{l}\text { Ruang Kepala } \\
\text { Madrasah }\end{array}$ & 1 & 1 \\
\hline 4 & Ruang UKS & 1 & 1 \\
\hline 5 & Mushola & 1 & 1 \\
\hline 6 & $\begin{array}{l}\text { Ruang } \\
\text { Perpustakaan }\end{array}$ & 0 & 0 \\
\hline 7 & Ruang Gudang & 1 & 1 \\
\hline 8 & Ruang Tahfidz & 1 & 1 \\
\hline 9 & Ruang BTAQ & 1 & 1 \\
\hline JUMLAH & 17 & 17 \\
\hline
\end{tabular}

Sumber: Profil MI Wahid Hasyim 2020

Keadaan siswa MI Wahid Hasyim adalah sebagai berikut

Tabel 6 Jumlah peserta didik tahun Pelajaran 2019/2020

\begin{tabular}{llll}
\hline No & Kelas & Jumlahsiswa & Rombel \\
\hline 1 & I & 37 & 2 \\
\hline 2 & II & 40 & 2 \\
\hline 3 & III & 41 & 2 \\
\hline 4 & IV & 30 & 1 \\
\hline 5 & V & 44 & 2 \\
\hline 6 & VI & 34 & 1 \\
\hline JUMLAH & 224 & 10
\end{tabular}

Sumber: Profil MI Wahid Hasyim 2020

Keadaan siswa MI Wahid Hasyim adalah sebagai berikut

Tabel 7 Keadaan Guru dan Karyawan No Keterangan Laki- Perempuan Jumlah

\begin{tabular}{lllll}
\hline 1 & Guru PNS & 1 & 1 & 2 \\
\hline 2 & $\begin{array}{l}\text { Guru Non } \\
\text { PNS }\end{array}$ & 7 & 11 & 18 \\
\hline 3 & $\begin{array}{l}\text { Karyawan } \\
\text { PNS }\end{array}$ & - & - & - \\
\hline 4 & $\begin{array}{l}\text { Karyawan } \\
\text { non PNS }\end{array}$ & 2 & 2 & 4 \\
\hline JUMLAH & 10 & 14 & 24
\end{tabular}

Sumber: Profil MI Wahid Hasyim 2020 
Meskipun secara administrasi tenaga pendidik dan kependidikan pada MI Wahid Hasyim berjumlah 24 orang, secara faktual jumlah yang berpartisipasi lebih dari 50 orang. Hal ini karena dibantu oleh Mahasantri PP Wahid Hasyim. Para santri Wahid Hasyim memiliki kewajiban untuk melakukan pengabdian. Salah satunya adalah dengan menjadi "guru pendamping" pada MI Wahid Hasyim (Wawancara Sukron, 24/9/2020).

MI Wahid Hasyim merupakan madrasah yang menerapkan pendidikan dasar berbasis pesantren modern yang mengedepankan pengembangan pribadi, tahfidzul Qur'an, dan penguasaan sains. Adapun salah satu misinya adalah mampu menghasilkan peserta didik yang berakhlak mulia dengan implementasi pengetahuan ajaran Islam dalam keseharian.

Ada beberapa keunggulan MI Wahid Hasyim yaitu

1. Perpaduan sistem kurikulum nasional, kurikulum kemenag yang dipadukan dengan kurikulum berbasis pesantren yang berfokus pada kemampuan: Sains, agama, sosial, literasi, dan seni. Guna meningkatkan kemampuan peserta didik pada bidang tersebut, MI Wahid Hasyim membentuk tim guru yang tangguh dari unsur santri senior yang mempunyai kemampuan melayani, mendampingi, dan mendidik siswa.

2. Penerapan model pembelajaran yang sesuai dengan tuntutan perubahan zaman abad 21, yaitu Pembelajaran berbasis IT

3. Menyeimbangkan kemampuan life skill dan soft skill

4. Sistem boarding school. Pendampingan 24 jam dalam penerapan kemampuan life skill dan soft skill. Sehingga tercapai generasi tangguh yang siap dengan tantangan global.

Keempat paradigma tersebut diramu dengan model pembelajaran STEAM (science, technology, engginering, art, mathematics) paduan lintas ilmu yang dapat membentuk pola pikir logis dan sistematis. Sehingga perpaduan empat paradigma dengan model pembelajaran tersebut dapat mewujudkan peserta didik yang sesuai dengan Motto MI WeHa : "Moeslm Generation Future Leader".

Model pembelajaran pada MI Wahid Hasyim dengan pola pendekatan STEAM, terdiri atas science, technology, engineering, art, dan mathematic. STEAM dipilih sebagai metode pembelajaran terpadu dengan pendekatan yang mendorong siswa berpikir secara meluas tentang masalah di dunia nyata, sehingga mendukung pengalaman belajar berorientasi pemecahan masalah. Semua aspek dalam STEAM merupakan kerangka berpikir sistematis untuk memahami ilmu pengetahuan dan implementasi dalam kehidupan seharihari.

Inti fondasi pendekatan pembelajaran model STEAM adalah pembelajaran inkuiri, berbasis proses, dan pemikiran kritis. Berbasis proses merujuk pada proses pembelajaran dengan menyediakan pertanyaan/ masalah (mendorong siswa aktif bertanya), kemudian memancing rasa keingintahuan (curiosity), setelah itu dapat merumuskan solusi dari pertanyaan/masalah yang diberikan. Oleh karenanya, berusaha menjadikan siswa lebih kreatif dalam menemukan solusi setiap masalah adalah inti dari metode STEAM.

Pada implementasinya, pembelajaran STEAM dipadukan dengan penekanan aturan dan tata terbit anak sholeh yaitu:

1) Jujur dalam melakukan kegiatan

2) Mengangkat tangan sebelum bertanya

3) Mendengarkan jika ada yang berbicara

4) Mampu berkompetisi dan bersaing

5) Mempunyai rasa kepedulian terhadap lingkungan dan orang lain

Dengan integrasi model pembelajaran STEAM dan rule anak sholeh yang ada siswa diajak belajar dengan cara menyenangkan. Stimulus yang diberikan guru dapat memupuk rasa ingin tahu siswa, 
menumbuhkan rasa percaya diri, dapat berpikir kritis, katalis dan juga memupuk rasa empatinya. Siswa mempunya sikap yang baik sesuai dengan salah satu goal pesantren yaitu peserta didik yang berakhlakul karimah.

Madrasah menjadi lembaga Pendidikan Islam yang penting untuk menciptakan kader-kader terbaik bangsa dengan wawasan keislaman dan kebhinekaan. Keunggulan utama madrasah adalah integrasi ilmu umum dan ilmu agama. MI Wahid Hasyim sebagai salah satu pendidikan Islam modern berbasis pesantren yang unggul di DIY bertugas meningkatkan kualitas SDM unggul dalam IMTAQ dan IPTEK.

MI Wahid Hasyim tetap menggunakan kurikulum nasional sebagai acuan pokok dan kurikulum muatan lokal sebagai pengembangan visi dan misi dengan ditunjang program-program unggulan yang berbasis pondok pesantren. Visinya mencetak moslem generation future leader, yang beriman, berilmu, berakhlak mulia, berdedikasi dan berdisiplin tinggi sehingga memperoleh kesuksesan dalam kehidupan dunia maupun akhirat. Selain itu, lulusan diharapkan mampu menjadi pencerah yang bermanfaat bagi lingkungannya.

Kurikulum menjadi salah satu unsur yang berkontribusi signifikan dalam mewujudkan proses pengembangan kualitas peserta didik di masa mendatang, sehingga kurikulum harus mampu beradaptasi dengan tantangan dan kompetensi yang diperlukan di masa depan. Undang-Undang Nomor 20 Tahun 2003 tentang Sisdiknasi, Pasal 1 disebutkan bahwa kurikulum merupakan seperangkat rencana dan pengaturan mengenai tujuan, isi, dan bahan pelajaran serta cara yang digunakan sebagai pedoman penyelenggaraan kegiatan pembelajaran untuk mencapai tujuan Pendidikan tertentu. Kurikulum 2013 dikembangkan sebagai lanjutan pengembangan KBK 2004 dan KTSP 2006 dengan ruang lingkup kompetensi sikap, pengetahuan, dan keterampilan yang diintegrasikan secara terpadu dalam pembelajaran. Oleh karena itu, pada hakikatnya K-13 dikembangkan berdasarkan hasil evaluasi pelaksanaan KBK dan KTSP, sehingga MI Wahid Hasyim mengimplementasikan kurikulum K-13 dalam pelaksanaan pendidikan di sekolah.

Tujuan dari K-13 adalah memfasilitasi manusia Indonesia yang beriman, produktif, kreatif, inovatif, dan afektif serta mampu berkontribusi pada kehidupan bermasyarakat, berbangsa, bernegara serta peradaban dunia. Oleh karena itu, PBM diselenggarakan secara aktif, inovatif, kretif, efektif dan menyenangkan. Kondisi tersebut diharapkan mampu memfasilitasi terbentuknya peserta didik yang berpartisipasi aktif serta memberikan ruang bagi kreativitas dan kemandirian peserta didik sesuai dengan bakat, minat serta perkembangan fisik dan psikologisnya.

MI Wahid Hasyim mengimplementasikan struktur kurikulum sebagai berikut: (1) kompetensi inti sebagai terjemahan atau operasionalisasi SKL dalam bentuk kualitas; (2) mata pelajaran yang terdiri atas 13 mata pelajaran; (3) bahasa jawa sebagai muatan local; (4) pengembangan diri melalui kegiatan pengembangan bakat dan minat yang tersedia dalam ekstra kurikuler. Disisi lain, Beban belajar MI Wahid Hasyim menggunakan sistem paket yang merujuk pada sistem penyelenggaraan pendidikan yang mewajibkan peserta didik mengikuti seluruh program pembelajaran yang telah ditetapkan untuk setiap kelas sesuai dengan ketentuan kurikulum yang digunakan.

Pembentukan perilaku di MI Wahid Hasyim dilakukan melalui dua cara, yaitu kegiatan rutin dan kegiatan spontan. Kegiatan rutin yang dilaksanakan diantaranya doa sebelum mulai kegiatan, infak kelas, sholat dhuha berjamaah, sholat dhuhur berjamaah, kebersihan kelas. Sedangkan kegiatan spontan yang dilaksanakan diantaranya: membudayakan senyum, salam, sapa dan bersalaman kepada guru, pegawai, dan sesama siswa; (2) pembiasaan sopan santun 
kepada seluruh masyarakat; membudayakan membuang sampah sesuai tempatnya; (4) pembiasaan budaya hidup antri; (5) membudayakan saling menghargai pendapat orang lain; (6) membudayakan untuk meminta izin masuk atau keluar kelas atau ruangan; (7) membiasakan perilaku menolong atau membantu orang lain.

Program unggulan MI Wahid Hasyim adalah: (1) hafalan Alquran, (2) madin, (3) penguasaan bahasa asing, (4) bakat minat, (5) Kesehatan, (6) fun holiday (minggu ceria). Kegiatan terprogram pada MI Wahid Hasyim adalah (1) class meeting; (2) peringatan hari besar nasional dan Islam, (3) pembelajaran lapangan (luar kelas), (4) kemah rutin, dan (5) pembiasaan pesantren.

Berikut ini adalah prestasi MI Wahid Hasyim tiga tahun terakhir:

Tabel 8 Prestasi MI Wahid Hasyim

\begin{tabular}{|c|c|c|c|}
\hline No & ahun & & 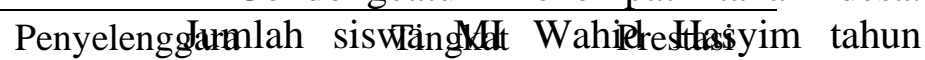 \\
\hline 1. & 2019 & & $\begin{array}{l}\text { Milad ke-1Petajajictn } 2020 / 2021 \text { sebannyak } 224 \text { siswa; } \\
\text { al-Kausar sebagian mengikutinst pembelajaran full day }\end{array}$ \\
\hline 2. & 2019 & & $\begin{array}{c}\text { Kampus A Aanksepagian (sekitar } 40 \% \text { \% adalah mondok. } \\
\text { Jumlah SDM pendidik dan tenaga }\end{array}$ \\
\hline 3. & 2019 & & 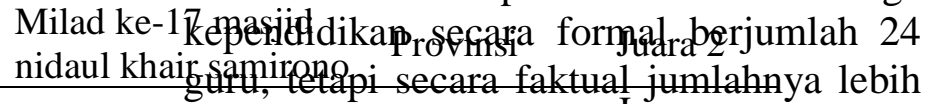 \\
\hline 4. & 19 & aya & $\begin{array}{l}\text { banyak karena dibantu olehrara ma masantri } \\
\text { Kec.Depok } \\
\text { PP Wahid Hasymatam. Keungarapan MI Man Mahid }\end{array}$ \\
\hline 5 & & & $\begin{array}{l}\text { Hasyim dilihat dari faktor kesejar } \\
\text { Kec. Depok } \\
\text { merupakan madrasahtan lama. } 3 \text { ara } 3\end{array}$ \\
\hline 6. & 2017 & $\begin{array}{l}\mathrm{M} \\
\mathrm{Q}\end{array}$ & Kec. Depok $\quad$ Kecamatan Juara 2 \\
\hline 7. & 7 & Quran & okUCAPAN TERIMA KASIH \\
\hline 8. & & idato Bahasa Jawa & Penulis mengucapkan terima ka \\
\hline & 2016 & Robotik & pada semuakakihak yang \\
\hline \multicolumn{4}{|c|}{ 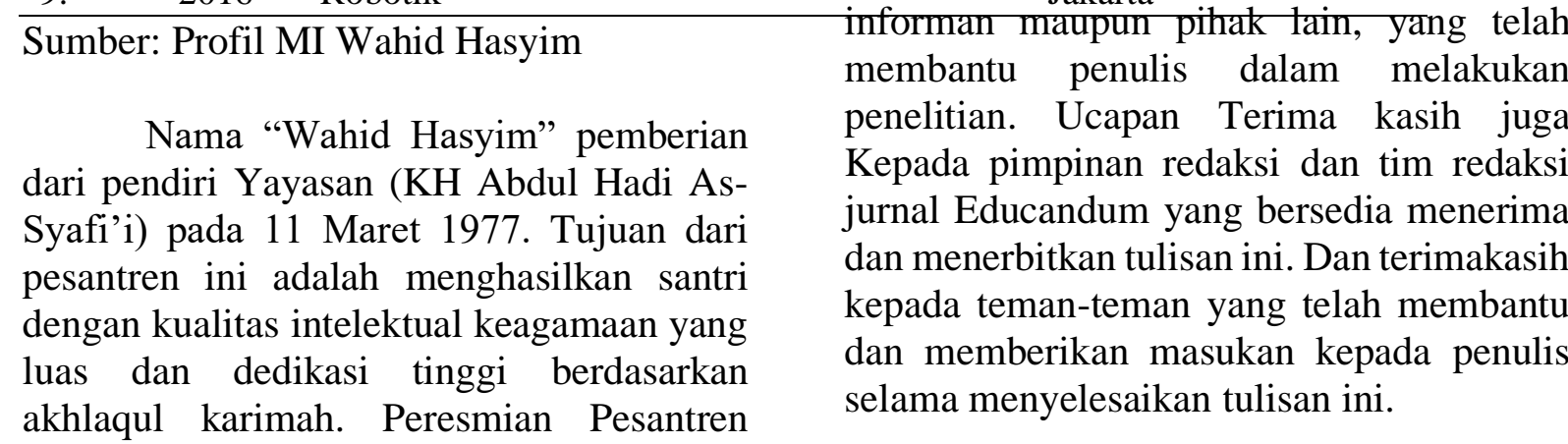 } \\
\hline
\end{tabular}

Yayasan tersebut merupakan pendidikan islam berbasis: (1) pembudayaan Akhlaqul karimah, (2) tahfidzul qur'an, (3) bahasa asing, dan (4) kitab kuning. Pondok pesantren ini memiliki banyak lembaga pendidikan sebagai yayasan penyelenggara, salah satunya adalah MI Wahid Hasyim.

\section{PENUTUP}

Best Practice pengelolaan MI Wahid Hasyim yakni integrasi penuh dengan pondok pesantren Wahid Hasyim. Madrasah ini merupakan kelanjutan dari MI Ma'arif Gaten di bawah pengelolaan LP Ma'arif sejak tahun 1966. Tahun 1995 berubah menjadi MI Wahid Hasyim di bawah pengelolaan pesantren. Sejak tahun 2018 ruang belajar MI Wahid Hasyim berpindah dari pesantren, Jl Wahid Hasyim No 3 ke Gedung MI yang baru di Jl Cendrawasih No 1 Condongcatur menempati tanah desa. ditandai dengan terbentuknya Yayasan Pondok Pesantren Wahid Hasyim pada 12 Oktober 1994 M/7 Jumadil Ula 1415 H. 


\section{DAFTAR PUSTAKA}

Arif, M. (2013). Manajemen Madrasah dalam Upaya Peningkatan Mutu Pendidikan Islam. Epistemé: Jurnal Pengembangan Ilmu Keislaman. https://doi.org/10.21274/epis.2013.8.2. 415-438

Hibana, H., Kuntoro, S. A., \& Sutrisno, S. (2015). Pengembangan Pendidikan Humanis Religius di Madrasah. Jurnal Pembangunan Pendidikan: Fondasi Dan Aplikasi. https://doi.org/10.21831/jppfa.v3i1.59 22

Maknun, M. L. (2014). Implementasi Tradisi Ikhtilaf dan Budaya Damai pada Pesantren Nurul Ummah dan Pesantren Ar-Romli Yogyakarta. Analisa. https://doi.org/10.18784/analisa.v21i0 2.18

Sallis, E. (2014). Total quality management in education: Third edition. In Total Quality Management in Education: Third Edition. https://doi.org/10.4324/978020341701 0

Sofanudin, A. (2012a). Minat Masyarakat terhadap Model Pendidikan Madrasah di Magelang dan Demak. EDUKASI: Jurnal Penelitian Pendidikan Agama Dan Keagamaan. https://doi.org/10.32729/edukasi.v10i3 .170

Sofanudin, A. (2012b). Model Peningkatan Minat Masyarakat terhadap Madrasah Ibtidiyah di Jawa Tengah. 6(Mei). Retrieved from https://journal.walisongo.ac.id/index.p $\mathrm{hp} / \mathrm{Nadwa} /$ article/view/459/419
Sofanudin, Aji., Rokhman, F., Wasino, \& Rusdarti. (2016). Quality-Oriented Management of Educational Innovation at Madrasah Ibtidaiyah. Journal of Education and Practice.

Sofanudin, A. (2016a). Manajemen Inovasi Pendidikan Berorientasi Mutu Pada MI Wahid Hasyim Yogyakarta. Cendekia: Journal of Education and Society. https://doi.org/10.21154/cendekia.v14i 2.820

Sofanudin, A. (2016b). Model Peningkatan Minat Masyarakat terhadap Madrasah Ibtidaiyah di Jawa Tengah. Nadwa. https://doi.org/10.21580/nw.2012.6.1.4 59

Sofanudin, A. (2018). Integrasi Pendidikan Formal dan Nonformal (Respon Satuan Pendidikan terhadap Kebijakan FDS). In D. Ahwan Fanani (Ed.), Kapita Selekta KF Doktor; Melintasi Tapal Batas Keilmuan (Pertama, pp. 1-26). Bogor: IPB Press.

Sofanudin, A. (2019). Best Practice Implementasi Kurikulum pada Sekolah Alam Insan Mulia (SAIM) Surabaya. Jurnal SMART (Studi Masyarakat, Religi, Dan Tradisi). https://doi.org/10.18784/smart.v5i1.74 4

Sofanudin, A. (2020). Penyebarluasan Best Practice Madrasah Ibtidiyah. Policy Brief Balai Litbang Agama Semarang.

Taruna, M. M. (2009). Manajemen Kurikulum di Madrasah Diniyah Nurul Ummah Kota Gede D.I. Yogyakarta. Analisa.

https://doi.org/10.18784/analisa. v16i1.61 